\title{
O desenvolvimento da vitivinicultura e as possibilidades de implantação de roteiros enoturísticos na Região de São Joaquim (SC, Brasil) $)^{1}$
}

\author{
The development of viticulture and the possibilities of implantation wine \\ tourism routes in the Region of São Joaquim (SC, Brazil)
}

\section{El desarrollo de la vitivinicultura y las posibilidades de implantación de las rutas del enoturismo en la Región de São Joaquim (SC, Brasil)}

\author{
Flavia Baratieri Losso ${ }^{2}$ \\ Raquel Maria Fontes do Amaral Pereira ${ }^{3}$
}

\begin{abstract}
Resumo: Partindo da análise das origens e desenvolvimento da vitivinicultura na região de São Joaquim (SC), o presente artigo propõe roteiros enoturísticos para uma área da Serra Catarinense já reconhecida por sua experiência com o segmento de turismo no espaço rural, com base em seus recursos paisagísticos e climáticos. Visando a consecução desses objetivos são enfocados a introdução e o desenvolvimento da produção de vinhos finos, bem como da atividade turística na região. Apesar de a investigação ter como foco central os municípios de Bom Retiro, São Joaquim, Urubici e Urupema, onde se encontram as empresas vitivinícolas com vinhos lançados no mercado desde 2004, a área de abrangência da pesquisa inclui também os municípios de Bom Jardim da Serra e Lages, em razão do seu significado para o incremento de atividades ligadas ao turismo. Como base teórica fundamental é utilizada a categoria de formação sócio-espacial aliada à ideia de combinações geográficas que, na análise do espaço geográfico, considera o modo como se combinam, ao longo do tempo, os elementos físicos, biológicos e humanos. O interesse pela vitivinicultura de altitude, suas origens, evolução e panorama atual em Santa Catarina, decorre do entendimento de que essa realidade apresenta-se como um novo potencial a ser explorado pelo turismo, tendo em vista as características paisagísticas singulares das áreas produtoras, os novos parâmetros de articulação dos recursos disponíveis e as estratégias de competitividade que tem afetado o mercado global e nacional de vinhos. Assim, pois, o cultivo da uva e a produção de vinhos na região de São Joaquim representam uma alternativa para o incremento da oferta turística regional, a partir da definição e implantação de roteiros para a prática do enoturismo.
\end{abstract}

Palavras-chave: Região de São Joaquim; Vinhos de altitude; Roteiros enoturísticos.

\footnotetext{
${ }^{1}$ Este artigo é oriundo da dissertação de mestrado intitulada "A produção de vinhos finos de altitude na região vitivinícola de São Joaquim (SC): uma alternativa para o turismo?" que foi defendida no ano de 2010, junto ao Programa de Mestrado em Turismo e Hotelaria da UNIVALI.

${ }^{2}$ Mestre em Turismo e Hotelaria pela UNIVALI. Atua como professora de ensino básico, técnico e tecnológico no Campus Florianópolis - Continente IFSC.E-mail: flavia@ifsc.edu.br

${ }^{3}$ Doutora em Geografia (Geografia Humana) pela Universidade de São Paulo. Atualmente é professora do Programa de Mestrado em Turismo e Hotelaria da UNIVALI, professora participante do Programa de Pós-Graduação em Geografia da UFSC e bolsista de Produtividade em Pesquisa do CNPq. E-mail: raquelfontespereira@gmail.com
} 
Abstract: Based on the analysis of the origins and development of viticulture in the region of São Joaquim (SC), this paper proposes wine tourism routes for an area of the Serra de Santa Catarina already recognized for their experience to the segment of tourism in rural areas, based on their climatic and scenic resources. In order to achieve those goals are focused on the introduction and development of production of fine wines, as well as tourism in the region. Although the investigation has focused on the central cities of Bom Retiro, São Joaquim, Urubici and Urupema, where are the wines with wine companies launched in the market since 2004, the coverage area of research also includes the cities of Bom Jardim da Serra and Lages, because of its significance for the development of activities linked to tourism. As a fundamental theoretical basis is used the category of socio-spatial formation allied to the idea of geographical combinations, the analysis of the geographical area, considering how they are combined, over time, the physical, biological and human. The interest in wine in altitude, its origins, evolution and current situation in Santa Catarina, stems from the understanding that this reality presents itself as a new potential to be exploited by tourism, in view of the natural landscape features of the producing areas, the new parameters of articulation of resources and strategies of competitiveness that has affected the global market and domestic wines. Thus, grape growing and wine production in the region of São Joaquim provides an alternative to the growth of regional tourism, from the definition and deployment scripts for the practice of wine tourism.

Keywords: Region of São Joaquim; Altitude wines; Wine tourism routes.

Resumen: Partiendo del análisis de los orígenes y desarrollo de la vitivinicultura en la región de São Joaquim (SC), este artículo propone itinerarios enoturísticos para un área de la Sierra Catarinense ya conocida por su experiencia con el segmento de turismo en el espacio rural, con base en sus recursos paisajísticos y climáticos. Para la consecución de esos objetivos son enfocados la introducción y el desarrollo de la producción de vinos finos, bien como la actividad turística en la región. A pesar de que el foco central de la investigación son los municipios de Bom Retiro, São Joaquim, Urubici y Urupema, donde se encuentran las empresas vitivinícolas con vinos lanzados en el mercado desde 2004, el área de alcance de la pesquisa incluye también los municipios de Bom Jardim da Serra y Lages, en razón de su significado para el incremento de actividades relacionadas al turismo. Como base teórica fundamental es utilizada la categoría de formación socio-espacial aliada a la idea de combinaciones geográficas que, en el análisis del espacio geográfico, considera el modo como se combinan, a lo largo del tiempo, los elementos físicos, biológicos y humanos. El interés por la vitivinicultura de altitud, sus orígenes, evolución y panorama actual en Santa Catarina proviene del entendimiento de que esa realidad se presenta como un nuevo potencial a ser explorado por el turismo, teniendo en vista las características paisajísticas singulares de las áreas productoras, los nuevos parámetros de articulación de los recursos disponibles y las estrategias de competitividad que han afectado el mercado global y nacional de vinos. De ese modo, el cultivo de la uva y la producción de vinos en la región de São Joaquim representan una alternativa para el incremento de la oferta turística regional, a partir de la definición e implantación de itinerarios para la práctica del enoturismo.

Palabras clave: Región de São Joaquim; Vinos de altitud; Itinerarios enoturísticos.

\section{INTRODUÇÃO}

O presente artigo utiliza como premissa o entendimento de que o turismo é um fenômeno socioeconômico, político e cultural e, como tal, passível de ser analisado por meio de categorias de análise espacial propostas por Milton Santos, as quais pretendem avaliar um 
determinado espaço numa perspectiva que contempla os aspectos naturais e humanos característicos de cada lugar, visto que todo espaço é construído socialmente . "A revolução do turismo tem ensejado grande complexidade de relações, tanto entre as pessoas e os componentes físicos da natureza quanto entre os grupos sociais, exigindo maior exploração dos recursos disponíveis" (Xavier, 2007, p. 75), o que aponta para o dinamismo desta atividade de abrangência mundial que reflete os valores e as necessidad es das sociedades atuais.

O presente trabalho analisa o desenvolvimento da produção de vinhos finos ${ }^{4}$ e da atividade turística na região vitivinícola de São Joaquim (SC) e, para tanto, enfatiza a formação sócio-espacial regional, sua origem e evolução, visando à caracterização das determinações naturais e humanas responsáveis por sua configuração, no passado e no presente.

Cabe destacar que o setor de vitivinicultura de altitude é o foco principal da pesquisa, o que exige a compreensão de suas origens, expansão e panorama atual, retratando-o como um novo potencial a ser explorado pelo turismo, tendo em vista as características paisagísticas singulares das regiões produtoras, bem como as sensíveis modificações que tem afetado o mercado global e nacional de vinhos.

Nos últimos anos, diversas ações do governo do estado de Santa Catarina, como o Programa de Ação Conjunta de Revitalização e Desenvolvimento (Acorde) da região de São Joaquim e o Plano de Marketing Turístico do Estado de Santa Catarina (Plano Catarina), demonstram que o destino turístico "Serra Catarinense" pode ser mais procurado, tornando mais expressiva a necessidade de investimentos que permitam o incremento de sua oferta turística.

A região de São Joaquim integra o conjunto de 65 destinos turísticos escolhidos pelo Ministério de Turismo para serem estimulados ao alcance de padrão internacional de qualidade, onde a distribuição de recursos e a execução de projetos de regionalização do setor serão prioridade para as cidades que compõem as regiões indutoras, permitindo o planejamento de toda a cadeia produtiva, no intuito de desenvolver o turismo regional.

A percepção de que o vinho pode ser fator de permanência cultural, visto a partir de uma ideologia, como fator de expressão da identidade e dos hábitos alimentares de sua região produtora (ou de quem o produz), justifica a percepção do enoturismo ${ }^{5}$ como facilitador do desenvolvimento regional por meio da "venda" do território turístico a partir de sua própria origem e identidade cultural.

Considerando a relação que se estabelece entre as atividades de turismo e de

\footnotetext{
${ }^{4}$ No Brasil, é importante diferenciarmos os vinhos finos dos vinhos de mesa. Os vinhos finos são os vinhos elaborados com as uvas europeias (vitis viníferas), como Chardonnay, Cabernet Sauvignon, Merlot e muitas outras. Os vinhos de mesa são os vinhos elaborados com as variedades de uvas americanas (não viníferas) e são conhecidos como 'vinhos de garrafão'.

${ }^{5}$ Com base nas leituras dos trabalhos de Hall (2004) e Falcade (2001) defini-se do enoturismo como a atividade representada pelo deslocamento das pessoas às regiões produtoras de uva e vinho, sendo evidenciada através das visitações aos vinhedos, às vinícolas, aos festivais e festas da uva e do vinho, no intuito de vivenciar na prática as características de uma região que apresente em sua economia a atividade vitivinícola.
} 
vitivinicultura, espera-se que um produto como o vinho fino de altitude da região de São Joaquim possa intervir na economia local agregando valor e influenciando, ainda mais, os fluxos turísticos regionais.

\section{FUNDAMENTAÇÃO TEÓRICO-METODOLÓGICA}

A área objeto (Figura 1) deste estudo refere-se aos municípios de São Joaquim, Urubici, Bom Retiro, Urupema, Bom Jardim da Serra e Lages. Os municípios de Lages e Bom Jardim da Serra se mantêm na área de referência por sua significativa importância no desenvolvimento do turismo regional da Serra Catarinense. Já os municípios de São Joaquim, Urubici, Urupema e Bom Retiro concentram as empresas vitivinícolas que apresentam vinhos comercializados no mercado nacional desde 2004.

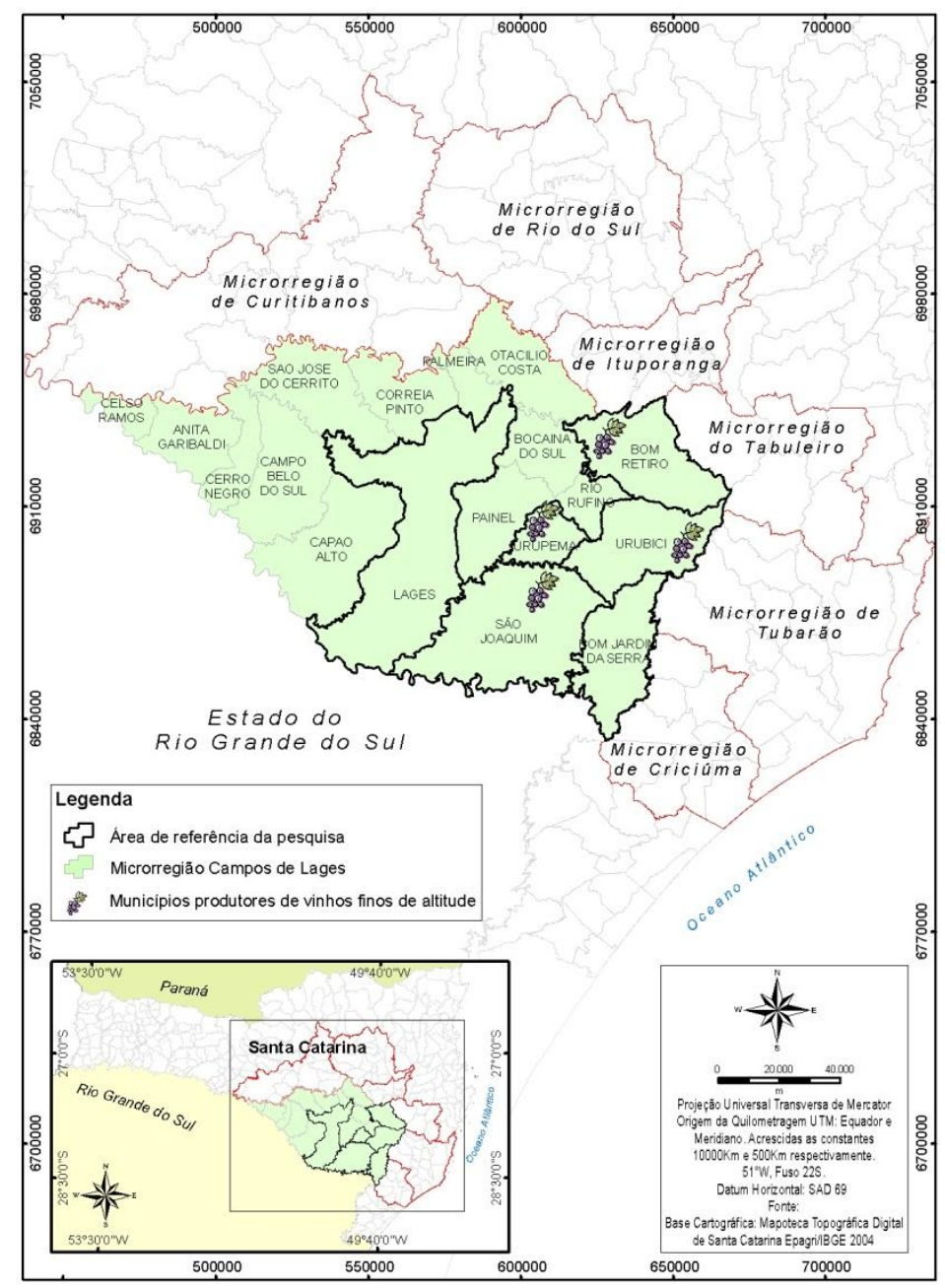

Figura 1. Representação geográfica da área objeto da pesquisa. Fonte: Elaboração pelas autoras e pela geógrafa Renata Duzzioni, (2010). 
Para analisar a realidade sócio-espacial da área objeto deste estudo, utilizou-se como referencial teórico-metodológico a Formação Sócio-Espacial proposta por Milton Santos, que reúne uma multiplicidade de determinações analíticas, de ordem natural e humana, que combinadas permitem um maior conhecimento da realidade empírica, partindo do entendimento do modo como evoluem as forças produtivas e as relações de produção.

$\mathrm{Na}$ verdade, Milton Santos, conforme destaca Mamigonian (1996) em seu texto "A formação sócio-espacial como teoria e como método", publicado originalmente em 1977, discute o conceito de formação econômica e social, alertando para a ausência da categoria espaço, razão pela qual propõe o paradigma de formação econômica, social e espacial, partindo do entendimento de que "a história não se escreve fora do espaço e não há sociedade a-espacial" (Santos, 1982, p. 10). Assim, se o espaço é uma construção social, é necessário que o estudo de qualquer região leve em conta aspectos geográficos e históricos, partindo da esfera da produção.

Aliado a esse posicionamento, o trabalho se apoiou também nas ideias difundidas por A. Cholley que sugere considerar, na análise da organização espacial, a combinação da totalidade dos elementos responsáveis pela sua configuração ao longo do tempo. Assim, "quando procuramos reduzir a realidade geográfica a seus elementos mais simples, chegamos à noção de combinação de complexo, expresso, essencialmente, por fenômenos de convergência" (Cholley, 1964, p. 139), sejam eles físicos, biológicos ou humanos.

Desta forma, para atingir com êxito os propósitos deste estudo, optou-se pela realização de uma pesquisa histórica e exploratória, de abordagem qualitativa. O estudo exigiu inicialmente uma revisão bibliográfica sobre a região do planalto catarinense e sobre a origem da vitivinicultura no país e no estado de Santa Catarina. Na fase exploratória da pesquisa, recorreu-se aos dados disponíveis em órgãos e entidades relacionados ao setor vitivinícola e turístico. Após esta etapa, o estudo desenvolveu-se através da aplicação de 20 entrevistas semiestruturadas direcionadas ao setor vitivinícola e ao setor turístico da região.

\section{ORIGENS DA VITINIVICULTURA NA SERRA CATARINENSE}

A evolução da vitivinicultura brasileira se confunde com o desenvolvimento desta atividade econômica no estado do Rio Grande do Sul que é referência nacional no cultivo de uvas vitis viníferas, na produção de vinhos finos e na capacitação de mão de obra para este setor.

A atividade de vitivinicultura teve grande importância para a fixação da cultura italiana no Sul do Brasil e principalmente, para o desenvolvimento econômico da região da Serra Gaúcha, englobando os municípios de Bento Gonçalves, Flores da Cunha, Garibaldi, Farroupilha, Caxias do Sul, entre outros (Aguiar, 2008). O fato é que estes imigrantes italianos (provenientes em sua maioria do Norte da Itália) tinham experiência no cultivo da vinha e na 
produção do vinho e trouxeram consigo sua expressiva tradição, tornando-se um elemento facilitador para a transição de uma produção doméstica para o estabelecimento do comércio do vinho no país.

Em Santa Catarina, a evolução da vitivinicultura apresenta características semelhantes ao ocorrido no estado do Rio Grande do Sul. Com a vinda dos colonizadores açorianos no século XVIII, surgem as primeiras tentativas de produzir vinhos no Estado e neste período, por motivos variados ${ }^{6}$, a atividade não progrediu na Província de Santa Catarina (Cordeiro, 2006). Foram as primeiras mudas de uva plantadas pelos imigrantes italianos que chegaram, em 1878, na região onde seria fundada a cidade de Urussanga ${ }^{7}$, as responsáveis pelo início da vitivinicultura catarinense que conhecemos hoje (Lombardo, 2009).

A produção brasileira de vinhos está se transformando e se atualizando segundo os critérios de qualidade adotados em regiões produtoras de países do Velho e do Novo Mundo. Cada região produtora busca hoje sua identidade no mercado, no intuito de se destacar frente à concorrência. Particularmente, a abertura comercial do Brasil, a partir da década de 1990, estimulou o consumo de vinhos importados através do aumento de opções de produtos diferenciados em termos de marcas, variedades e denominações de origem (Tonietto, 2003). Esta situação obriga o produto nacional, em fase de desenvolvimento de marcas e características organolépticas ainda recentes, a disputar o mercado interno de vinhos finos com marcas e produtos já consolidados e reconhecidos pelo consumidor brasileiro (Blume, Hoff, \& Pedrozo, 2007).

Surge um novo cenário, no qual emergem consumidores mais exigentes, que buscam conhecer mais sobre a qualidade, a procedência e a diversidade do vinho, tornando este mercado ainda mais competitivo para os vinhos produzidos no Brasil (Tonietto, 2003).

É de extrema importância enfatizar que desde o final da década de 1990 novos investidores surgem no mercado brasileiro de vinhos, como é o caso das empresas que se instalaram nos estados do Paraná, São Paulo, Minas Gerais e Santa Catarina, onde muitas ainda estão por lançar seus vinhos.

$\mathrm{O}$ andamento da pesquisa demonstrou que o surgimento da atividade de vitivinicultura de altitude na região de São Joaquim está intimamente relacionado às suas condições geoclimáticas, às diferentes fases de seu crescimento e à diversificação da economia local, contrariando o padrão de grande parte das vinícolas até hoje estabelecidas nas regiões tradicionais do Rio Grande do Sul e de Santa Catarina que tiveram origem no período das

\footnotetext{
6 "Na década de 40 um fato novo desacelerou a vitivinicultura em Urussanga: a ascensão da atividade carbonífera atraiu agricultores, e como houve queda na produção a região precisou comprar uvas do Rio Grande do Sul para fazer vinhos" (Lombardo, 2009, p. 51).

7 “[...] na região Carbonífera há cerca de 120 produtores, que fabricam cerca de 3,5 milhões de litros de vinho. $A$ região distingue-se por apresentar a produção de uma uva característica, a Goethe, que possui qualidades próprias que diferenciam o seu vinho das demais cultivadas no Brasil. É uma uva híbrida, com material genético de Vitis vinífera e Vitis labrusca, que apresenta aroma e paladar de frutas, e cuja tipicidade é um dos elementos que mais contribuem para a divulgação da bebida. Além da Goethe, a região produz outras variedades como a Niágara e a Bordô" (BRDE, 2005, p. 29).
} 
imigrações europeias, principalmente, a italiana.

Cabe destacar que a produção de vinhos finos de altitude em Santa Catarina concentrase em três regiões produtoras (Campos Novos, Caçador e São Joaquim) que integram a Associação Catarinense de Produtores de Vinhos Finos de Altitude (ACAVITIS), criada em 2005 com o intuito de promover uma marca de qualidade. As normas da ACAVITIS fixam alguns parâmetros para a produção que garantem o padrão e a qualidade dos vinhos finos de altitude da serra catarinense, como a altitude acima de 900 metros em relação ao nível do mar, a produção máxima de 6 (seis) mil litros de vinho por hectare de uvas, além da proibição da chaptalização (adição de açúcar ao mosto no intuito de elevar o teor alcoólico dos vinhos tranquilos).

Entre as três regiões produtoras de vinhos finos de altitude catarinense, já é possível destacar a expressividade da região de São Joaquim através do percentual de área plantada por município, com base em dados obtidos pela Epagri/Ciram (2009) ${ }^{8}$, os quais demonstram que São Joaquim responde por $51,5 \%$ da produção, Urupema com 6,1\% e Urubici com 0,5\%. Nesse espaço, incluindo o município de Urupema, encontravam-se instalados no ano de 2010 8 (oito) vinhedos com vinhos lançados no mercado a partir do ano de 2004, a exemplo da Villa Francioni e da Quinta da Neve. Entre os anos de 2011 e 2012, 3 (três) novas vinícolas Villaggio Bassetti, Vinhedos do Monte Agudo e Vinícola Hiragami - já lançaram seus vinhos no mercado nacional, o que demonstra o recente dinamismo da atividade nessa porção do território catarinense ${ }^{9}$.

A vinícola Quinta da Neve adquiriu sua propriedade de 87 hectares, localizada a $30 \mathrm{~km}$ do centro de São Joaquim, no ano de 1999, influenciada pelos experimentos da Epagri e pelo plantio de plantas experimentais de uvas Cabernet Sauvignon realizado pela vinícola Monte Lemos (detentora da marca Dal Pizzol). Seus atuais proprietários são os empresários Acari Amorim $^{10}$, Adolar e Edson Hermann, proprietários da Decanter ${ }^{11}$ e Robson Abdala ${ }^{12}$. 0 primeiro vinho lançado pela Quinta da Neve foi em 2004, safra 2003, e atualmente já possui 3

\footnotetext{
${ }^{8}$ Estes dados foram obtidos em contato com o pesquisador Luiz Fernando de Novaes Vianna referentes a uma pesquisa encomendada pela ACAVITIS ao Epagri/Ciram, ainda não publicada.

${ }^{9}$ A região da Serra Catarinense apresenta em sua gênese e evolução da formação sócio-espacial as seguintes atividades: 1) Tropeirismo (séc. XVIII) - deslocamento de tropas, índios e comércio de gado; 2) Latifúndio pastoril (séc. XIX) - afirmação do monopólio das terras e das estâncias pastoris; 3) Ciclo da madeira - primeiras serrarias em 1885, porém em 1940 ocorre o desenvolvimento e a expansão da indústria madeireira. A intensificação dos investimentos em reflorestamento ocorrerá em 1980; 4) Fruticultura de clima temperado - entre as décadas de 1950 e 1970 há o marco dos investimentos neste setor, com a estruturação de produção para a maçã em 1980. A partir de 1990 acontece a intensificação e a consolidação do mercado da maçã. A reestruturação da produção e a diversificação de plantio serão identificadas também na década de 1990.

${ }^{10}$ Acari Amorim é editor de revistas e livros, enófilo, integrante da Associação Brasileira dos Sommeliers - ABS do Rio e de São Paulo.

${ }^{11}$ A Decanter foi fundada em Blumenau, em 1997 e se situa entre as quatro maiores importadoras de vinhos do país, sendo a primeira na região Sul do Brasil.

12 O sócio da Quinta da Neve, Robson Abdalla, é engenheiro civil e empresário ligado à construção. Robson é enófilo e sua área profissional permitiu que supervisionasse desde o princípio a elaboração de todos os projetos da cantina, contando com a assessoria do enólogo português Anselmo Mendes.
} 
vinhos no mercado, Cabernet Sauvignon, Merlot e Chardonnay.

Em entrevista, Acari Amorim declarou que os sócios já investiram cerca de $\mathrm{R} \$ 3$ milhões e que com a construção da vinícola (com capacidade para 230 mil litros) os investimentos chegarão à R\$ 4 milhões. As obras para compor a estrutura de vinificação da Quinta da Neve só foram finalizadas após a colheita de 2010, portanto, para a safra do mesmo ano a vinificação ocorreu de forma terceirizada na estrutura da vinícola Santo Emílio (Lages) e na vinícola Amadeu (Bento Gonçalves). Nos anos anteriores o serviço de vinificação para a Quinta da Neve era efetuado pela Villa Francioni (São Joaquim).

Outro investimento pioneiro ocorreu no ano de 2000 idealizado pelo empresário Dilor de Freitas $^{13}$ quando adquiriu uma propriedade no município de Bom Retiro, onde em 2001 iniciou o cultivo de 19 hectares de uvas finas. No ano de 2002 adquiriu sua propriedade de São Joaquim, localizada a 1260 metros de altitude, iniciou o cultivo e lançou a construção de sua vinícola onde se localizaria a sede da Villa Francioni (Figura 2).

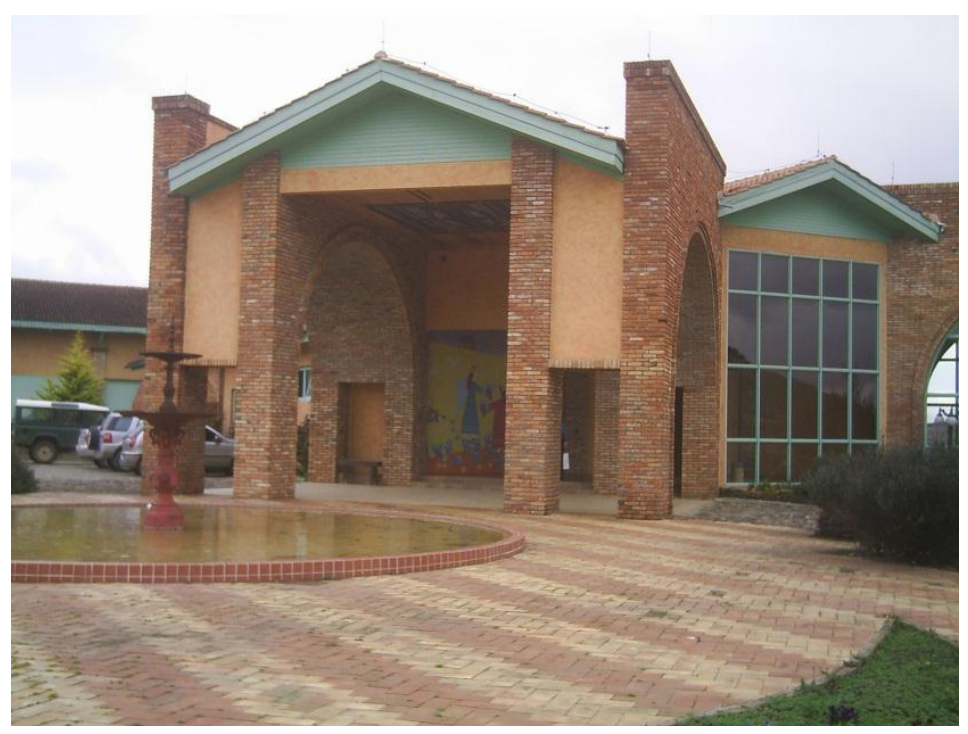

Figura 2. Fachada da Vinícola Villa Francioni, São Joaquim. Fonte: Acervo das autoras, (2009).

O projeto da vinícola reflete a qualidade pretendida pelo idealizador Dilor de Freitas. A construção apresenta-se em seis níveis para que possa aproveitar o fluxo gravitacional durante o processo de vinificação, evitando ao máximo o uso de transferências mecânicas.

\footnotetext{
13 Manoel Dilor de Freitas foi empresário do sul do estado ligado à extração carbonífera e ao setor cerâmico. O conglomerado Cecrisa, controlado pelas famílias de Manoel Dilor de Freitas e Álvaro Roberto de Freitas Arns (tio e sobrinho), acumula negócios nas áreas de revestimentos cerâmicos, mineração, colorifício, transporte, comunicação, reflorestamento e construção civil. A maior e mais conhecida das firmas é a Cecrisa Revestimentos Cerâmicos, de capital aberto, composta por cinco fábricas no Brasil.
} 
A rica obra arquitetônica da Villa Francioni reafirma o modelo que a vitivinicultura do Novo Mundo vem aplicando, onde esta serve como elemento atrativo do enoturismo. Ao se considerar a arquitetura como uma expressão do momento, naturalmente esta acompanhará o processo de evolução tecnológica incorporado pelo universo da vitivinicultura, em que as construções projetadas para a elaboração de vinhos começam a romper padrões relacionados aos modelos culturais dos tradicionais países produtores de vinho.

Em suma, pode-se considerar que esta inovação na arquitetura do vinho expressa três fundamentos: a construção do vinho em si; a construção do ambiente em que o vinho é elaborado; e a psicologia inerente ao novo consumidor do vinho, já que este incorpora e expressa para o consumidor a imagem do ambiente em que ele é elaborado (Confraria do Vinho, 2010).

Segundo o depoimento do enólogo da vinícola, Orgalindo Bettú, o capital investido na Villa Francioni se mantém no Grupo Cecrisa, "era uma Ltda que foi transformada numa S/A quando os 4 filhos herdaram os negócios com o falecimento do pai Dilor de Freitas". Hoje, a administração do empreendimento vitivinícola é mantida em sistema de Conselho Administrativo onde há um rodízio entre os filhos para a ocupação do cargo de Presidente do Conselho.

Entre os investidores pioneiros dessa nova fase da vitivinicultura catarinense, além das empresas já citadas, se destacam os seguintes investimentos que no ano de 2010 já comercializavam seus vinhos (empresa, local, ano de fundação): Vinícola Suzin, São Joaquim, 2001; Quinta Santa Maria, São Joaquim, 2004; Sanjo, São Joaquim, 2002; Santo Emílio, Urupema, 2004; Serra do Sol, Urubici, 2004; e Pericó, São Joaquim, 2007.

É interessante notar que os investidores tiveram seu interesse despertado para o universo do vinho de uma forma muito pessoal, levados pela constatação de que o vinho acompanha a humanidade a mais de 6.000 anos e ainda exerce tamanho fascínio, capaz de despertar o empreendedorismo de empresários ligados a diferentes setores, como o setor têxtil, o cerâmico, a fruticultura, a pecuária e até mesmo profissionais liberais da área da saúde, como é o caso do médico oftalmologista Ernani Abreu que aplica $R \$ 2$ milhões de recursos próprios com Janaína Soares de Abreu na vinícola Abreu Garcia, em Campo Belo do Sul, numa área de 7,2 hectares de vinhedo.

Assim como a Sanjo, o fruticultor Fumio Hiragami ${ }^{14}$ que iniciou na produção de maçãs em 1974, sendo um dos pioneiros na região, investe na diversificação de sua produção, com o cultivo de pêssego, pera, kiwi e uva. Este último, iniciado em 2006, é destinado exclusivamente para a produção de sua nova marca de vinhos finos de altitude e já está dando frutos, com o lançamento de 2 espumantes, 1 vinho branco e 3 vinhos tintos na

\footnotetext{
${ }^{14} \mathrm{O}$ Sr. Fumio Hiragami faz parte do grupo dos primeiros japoneses que se instalaram em São Joaquim através de um projeto de fruticultura da Cooperativa Cotia. Ele decidiu vir para a cidade enquanto seu irmão permaneceu em São Paulo trabalhando com o cultivo de verduras e hortaliças. Ao perceber que algo estava errado na cooperativa, ele e o irmão decidiram fundar sua própria empresa, mantendo o cultivo em São Joaquim e a comercialização em São Paulo.
} 


\section{Expovinis Brasil 2011.}

De acordo com o relato de Celito Soldá ${ }^{15}$, responsável pelo cultivo das macieiras e demais frutas da Hiragami, a empresa iniciou seus testes com a vitivinicultura em 2001 com a uva Cabernet Sauvignon e outras variedades, porta enxertos e sistemas de condução sob a supervisão da Epagri em propriedades nos municípios de Painel e São Joaquim (local chamado de Colônia Cotia, a 5 km do centro), abrangendo em 2010 uma área de aproximadamente 6,5 hectares de uvas viníferas.

A Hiragami efetuou as vinificações em parceria com a vinícola Villa Francioni (supervisão do enólogo Orgalindo Bettú) em três safras, e a última de 2010 foi com a vinícola Kranz, de Treze Tílias, sendo processados 20.000 kilos de uvas.

Outro empreendimento iniciado é a Villaggio Bassetti e seu investidor assumiu a presidência da ACAVITIS de dezembro de 2009 até novembro de 2011, antes mesmo de lançar seu primeiro vinho no mercado nacional que ocorreu agora em 2011 (2 vinhos tintos e 1 vinho branco). Eduardo Bassetti ${ }^{16}$ esclareceu que em 2005 adquiriu uma propriedade junto à Rodovia SC 438, acesso para São Joaquim via Lages, a 8 km do centro e $3 \mathrm{~km}$ da Villa Francioni. A localização da propriedade foi também escolhida em função da facilidade de acesso para futuros investimentos no setor de turismo.

Bassetti e seus dois irmãos (sócios) contrataram há dois anos um enólogo de Bento Gonçalves com mestrado em viticultura, Anderson de César, para ajudar na implantação e condução dos vinhedos e na fabricação do vinho. Hoje o vinho da Villaggio Bassetti está sendo produzido no Rio Grande do Sul, no Vale dos Vinhedos, em parceria com uma única vinícola de projeto muito semelhante.

Cabe destacar, também, que o capital investido nas vinícolas Villa Francioni, Quinta da Neve, Quinta Santa Maria, Pericó e Villaggio Bassetti, além de oriundos de outros setores que não a vitivinicultura, são externos à região de São Joaquim, o que promove um aporte de capital à região e um provável 'aquecimento' da economia local através da geração de emprego e renda.

O fluxo de investimentos nacionais ocorridos no setor de vitivinicultura nestes municípios nos primeiros anos desta atividade na região de São Joaquim pode ser visualizado a seguir, conforme Figura 3.

\footnotetext{
${ }^{15}$ Celito Soldá é gaúcho e formou-se engenheiro agrônomo pela Universidade de Passo Fundo. As oportunidades de trabalho o levaram a residir em São Joaquim, já que fez estágio na área da fruticultura, em Vacaria, especificamente na cultura da macieira.

${ }^{16}$ Eduardo Bassetti é natural de Curitiba (Paraná), mas vive a 20 anos em Florianópolis. Apesar de ser engenheiro químico, durante muito tempo trabalhou na área de comunicação, principalmente no ramo editorial e desde 2009 se afastou deste setor para se dedicar ao seu novo empreendimento. Disse que seu avô produzia vinho de mesa (com uvas americanas) no interior do Paraná e esta relação estabelecida com a bebida desde sua infância o fez averiguar a viabilidade de investir na vitivinicultura.
} 


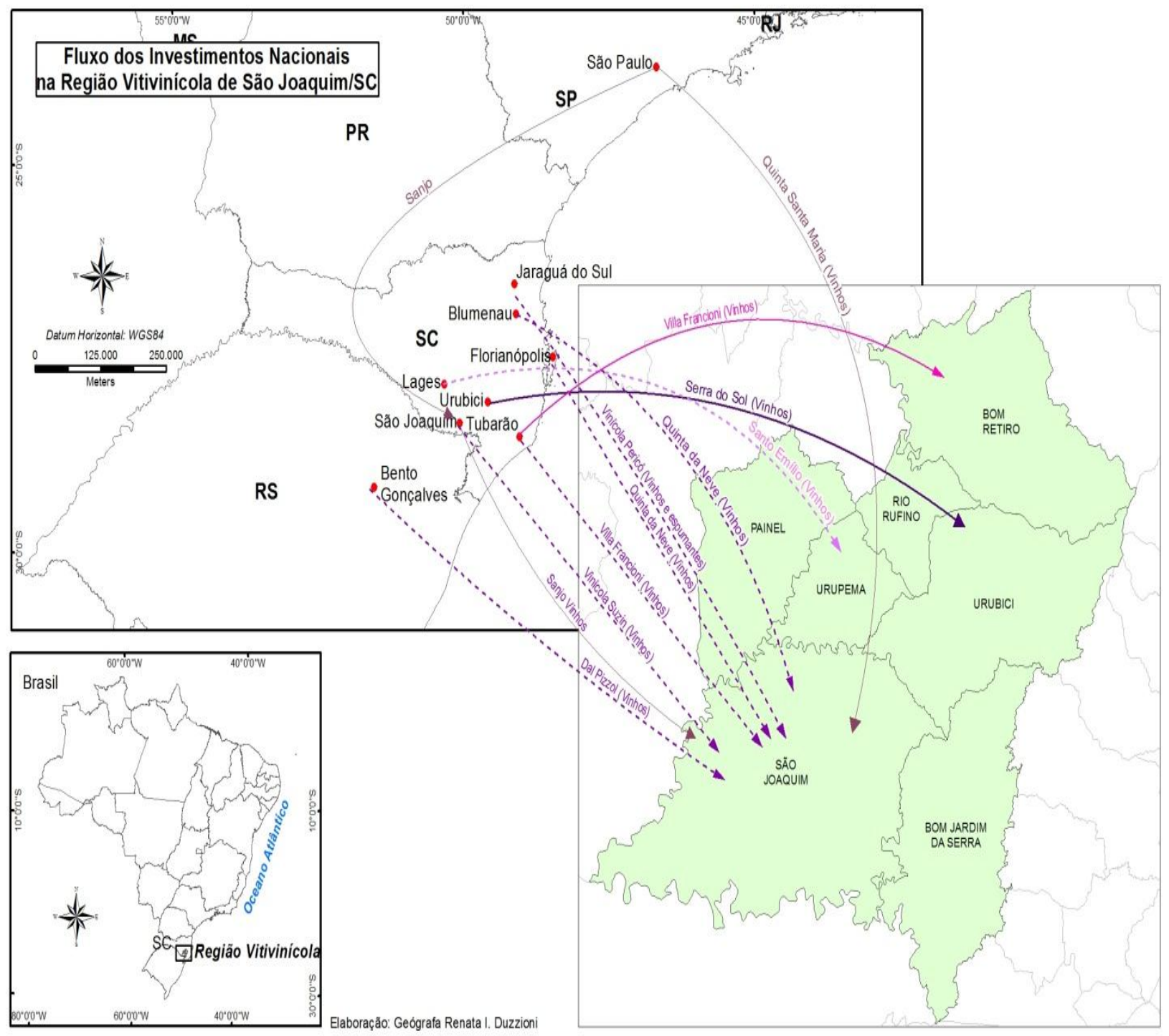

Figura 3. Fluxos de investimentos nacionais na vitivinicultura da Região de São Joaquim. Fonte: Elaboração pelas autoras e pela geógrafa Renata Duzzioni, (2010).

A Figura 3 destaca um aspecto importante e que merece ser enfatizado: o empreendedorismo e o intenso dinamismo econômico do Estado de Santa Catarina que faz com que haja iniciativas de empresários procedentes de outras regiões que venham aplicar seu capital em novas empresas e novas atividades, dinamizando assim, a própria região de São Joaquim, que tem origem no latifúndio pastoril.

A distribuição geográfica de parte dos empreendimentos vitivinícolas instalados na região de São Joaquim é apresentada na Figura 4: 


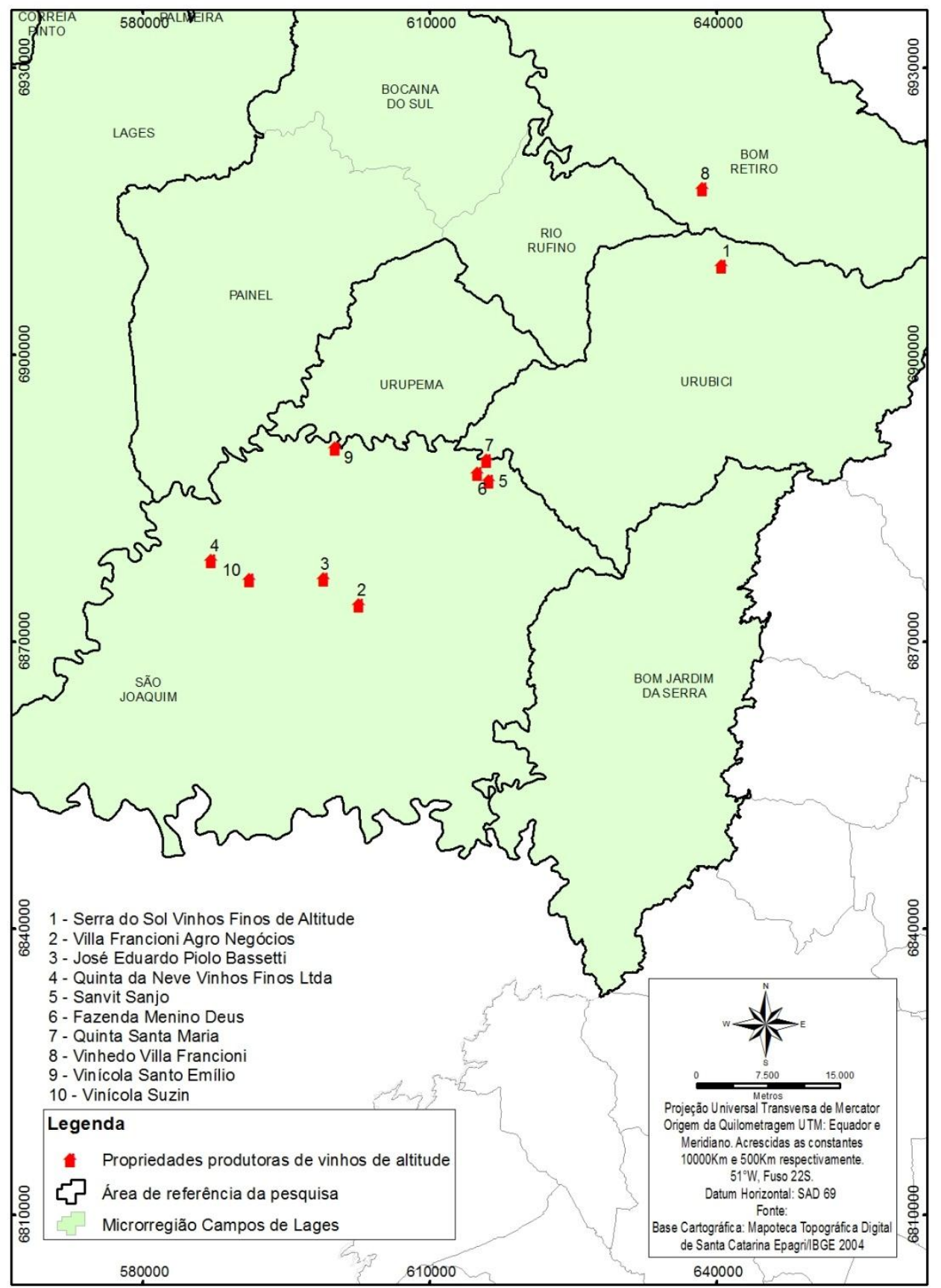

Figura 4. Distribuição dos empreendimentos vitivinícolas na região de São Joaquim. Fonte: Elaboração pelas autoras e pela geógrafa Renata Duzzioni, (2010). 
Estes empreendimentos, vinculados aos serviços turísticos existentes na região, permitem uma análise da potencialidade para a definição de rotas e roteiros enoturísticos. Em relação à reconfiguração da vitivinicultura nacional face à reconversão do setor em âmbito mundial, aponta Aguiar (2008, p. 54) que:

as mudanças começam pela própria infraestrutura empresarial, mas também podem ser notadas na composição dos produtos, nas linhas, nos estilos e nas marcas oferecidos e no design mais estilizado e contemporâneo das garrafas e dos rótulos, os quais também trazem mais informações e atrativos para o consumidor.

De certo modo, as vinícolas apresentadas até o presente expressam seu interesse na busca pela qualidade e na estratégia do produto diferenciado, como estratégia para salvaguardar a competitividade, mobilizando o desejo de consumo pela singularidade, isto é, a atração e valorização do produto pelas características únicas obtidas nas áreas de altitude da Serra Catarinense. Aliado a este produto diferenciado, a inserção da atividade de turismo junto às instalações vitícolas apontam como uma tendência para a região, no sentido de promover tanto a região quanto o produto vinho fino de altitude.

\section{ROTEIROS ENOTURÍSTICOS NA REGIÃO DE SÃO JOAQUIM (SC)}

O vinho é um produto carregado de valor simbólico, associado à cultura, status, glamour, estética de uma sociedade ou classe social. Seus rituais de consumo e apreciação podem também ser responsáveis pela elitização da bebida: a taça para o vinho, a temperatura para degustação, a harmonização com as comidas. Aguiar (2008, p. 207) defende que "grande parte dos que emitem essa opinião especializada são, sobretudo, consumidores de vinhos de escalas de preço mais altas do que as dos consumidores da população me diana brasileira". De certo modo, a pesquisa demonstrou que a maior parte das vinícolas da Serra Catarinense tende a se posicionar com vinhos de padrão para conhecedores, os enófilos, mantendo sua competitividade junto aos segmentos de consumo das classes mais abastadas, que deverá refletir no perfil do enoturista da região.

Percebeu-se que a maioria dos empreendimentos vitivinícolas da região de São Joaquim planeja construir centros de visitação para os turistas, a fim de que possam conhecer e divulgar seus produtos. Destaca-se que as incursões turísticas nas vinícolas auxiliam na percepção dos visitantes em relação aos custos de produção do vinho, promovendo, assim, o consumo do excedente de produção, o que ficou evidenciado nas entrevistas realizadas em algumas empresas entrevistadas, que visam à maximização dos lucros.

O segmento de turismo no espaço rural, marco desta atividade sócio-econômica na Serra Catarinense, é reconhecido como a experiência turística que se reporta, primeiramente, 
ao meio rural dotado de atrativos primários na forma de importantes e bem divulgados recursos paisagísticos e climáticos. O turista é motivado pelo frio pela expectativa de ver e sentir a neve, mas identifica-se também com os aspectos socioculturais e a história regional (Lins, 2008).

É fato que a implantação da atividade turística na região dos Campos de Lages, a partir de meados da década de 1980, foi pioneira na exploração do turismo rural no Brasil e nasceu da iniciativa de alguns fazendeiros (Hotel Fazenda Pedras Brancas, Hotel Fazenda Boqueirão e Hotel Fazenda do Barreiro) devido à busca por novas alternativas de renda para suas tradicionais fazendas de gado.

Com a inserção das atividades vitivinícolas na região, surge a oferta do enoturismo, que desponta como uma atividade promissora, capaz de redirecionar a economia regional e apresentando-se como uma consequência aos investimentos vitivinícolas instalados. Atualmente o turista pode visitar em São Joaquim as instalações da Vinícola Villa Francioni, adequadas para as incursões enoturísticas, bem como a loja e a fazenda da Vinícola Quinta Santa Maria, que também oferece passeios aos vinhedos, com almoço servido às margens do rio que corta a propriedade.

O enoturismo traz, na sua essência de atividade econômica, a ideia de transformar o vinho em um evento cultural, valendo-se dos aspectos históricos e culturais das regiões produtoras. A atividade "se fundamenta na viagem motivada pela apreciação do sabor e aroma dos vinhos e das tradições e tipicidade das localidades que produzem a bebida" (Ansarah, 2005, p. 294). Este segmento do turismo porta-se como um grande negócio para a indústria do vinho, por garantir as vinícolas um rendimento paralelo, reforçando a venda direta dos produtos e possibilitando uma maior exposição da marca (Aguiar, 2008).

Todavia, para que o segmento do turismo do vinho contribua com o desenvolvimento local e regional, faz-se necessário que, assim como as vinícolas se organizam para receber os turistas, o destino turístico em sua totalidade saiba atrair e motivar a permanência destes visitantes. A criação das rotas de vinhos deve ser uma ação conjunta entre os órgãos públicos, as associações e instituições dos setores de vitivinicultura e turismo, os empreendimentos de hospedagem, alimentação e demais serviços turísticos e as vinícolas, tendo como base a melhoria das infraestruturas de acesso, transporte e sinalização, garantindo aos investidores uma base sólida para a implementação de sua oferta turística.

A pesquisa apontou para a viabilidade da implantação de um roteiro regional de enoturismo, conforme a Figura 5. Ressalta-se que o fato de existirem empreendimentos vitivinícolas em Bom Retiro, Urubici, São Joaquim e Urupema, possibilita a construção de uma rota integrada, composta de três opções de roteiros (Roteiros enoturísticos: Serra do Panelão Serra do Corvo Branco, Vinícolas do Pericó - Serra do Rio do Rastro e Central). Contudo, recomenda-se que o papel articulador seja da Associação Catarinense de Produtores de Vinhos Finos de Altitude (ACAVITIS), no sentido de mobilizar o setor turístico já instalado e o poder público regional. 


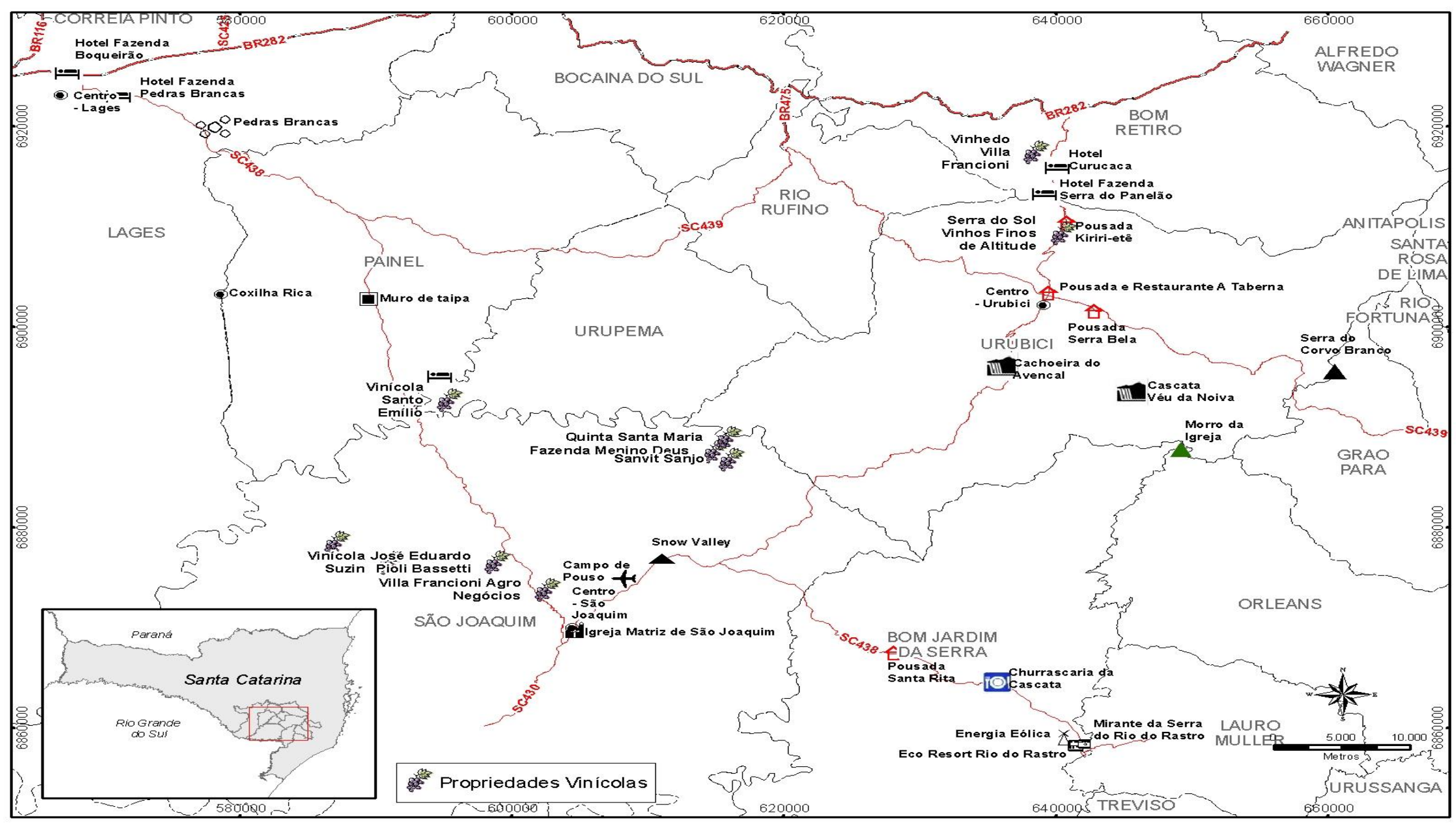

Figura 5. Rota enoturística da região de São Joaquim.

Fonte: Elaboração pelas autoras e pela geógrafa Renata Duzzioni, (2010). 
Há uma série de elementos a ser considerado na elaboração de uma rota de vinho, como a qualidade do vinho, os serviços turísticos, o comércio, a hospitalidade, a acessibilidade, os serviços básicos, a segurança, o ambiente limpo, a harmonia da paisagem, a tradição do meio rural, as atividades participativas, a interpretação, a assistência técnica, a promoção, dentre outros ${ }^{17}$. Neste sentido, no município de Bom Jardim da Serra destaca-se a Serra do Rio do Rastro, que além de ser uma via de acesso ligando o litoral e o planalto catarinense, representa a beleza e imponência da região dos cânions do Sul do Brasil. 0 mirante da Serra do Rio do Rastro apresenta-se como um dos principais atrativos da região e o equipamento de hospedagem mais bem estruturado, o Rio do Rastro Eco Resort, propriedade de Ivan Cascaes ${ }^{18}$, presidente do Convention \& Visitors Bureau Serra Catarinense.

Cabe ressaltar que os equipamentos turísticos apresentados na rota e roteiros sugeridos (Figura 5) foram escolhidos por serem representativos da oferta de serviços turísticos desta região.

Uma rota pode ser traçada em um momento específico, por decisão de mercado ou por política pública. Também pode ser desenhada como um produto novo, baseada em uma ideia original. Esta rota propõe a visitação aos vinhedos da localidade de Pericó (Sanjo, Quinta Santa Maria e Pericó) via passeios realizados em veículo of Road ou cavalgadas, devido à qualidade da via de acesso, além das opções de serviços de alimentação na Churrascaria da Cascata; de hospedagem e alimentação no Rio do Rastro Eco Resort ou Pousada Santa Rita; de visitação ao Mirante e Serra do Rio do Rastro e ao Parque Eólico (ainda em construção). O roteiro integra comunidades e equipamentos turísticos localizados nos municípios de Bom Jardim da Serra e São Joaquim.

Na Figura 5, podemos visualizar a sugestão de roteiro que integra estabelecimentos de Bom Retiro e Urubici que propõe a visitação ao vinhedo da Villa Francioni, em Bom Retiro (hoje a propriedade não está aberta à visitação, porém entre os projetos idealizados pelo Sr. Dilor de Freitas estava prevista esta estruturação) e ao vinhedo da vinícola Serra do Sol, em Urubici; os serviços de alimentação e hospedagem no Curucaca Hotel Fazenda, Hotel Fazenda Serra do Panelão, Pousada Kiriri-eté, Pousada e Restaurante A Taberna ou Pousada Serra Bela; além da visitação aos atrativos turísticos naturais, Cachoeira do Avencal, Cascata Véu da Noiva, Morro da Igreja (Pedra Furada) e Serra do Corvo Branco.

O grande número de opções de serviços de hospedagem presentes nesta proposta de roteiro demonstra a grande oferta existente na cidade, além do destaque dado aos atrativos naturais, devido ao fato de Urubici ser conhecida por sua natureza exuberante, que se

\footnotetext{
17 Slide de apresentação intitulado "Las Rutas del Vino como Planteamiento Estratégico para la Implantación del Turismo Enológico: la perspectiva de las AAPP" do Curso de Verão "Turismo Enológico", Universidade Internacional de Andaluzía Sede de La Rábida, ministrado pelo Prof. Dr. Enrique Torres Bernier.

${ }^{18}$ O Sr. Ivan Cascaes é de Orleans (Sul do Estado de Santa Catarina) e morou 46 anos em Florianópolis. Há 4 anos vive em Bom Jardim da Serra por causa de seu empreendimento turístico. O empresário Ivan Cascaes é mais um investidor que representa o empreendedorismo oriundo do Sul do Estado, cujo capital tem origem na pequena produção mercantil dos Vales Atlânticos onde se instalaram os imigrantes (áreas coloniais muito dinâmicas).
} 
mantém preservada, pelas matas de araucárias, cachoeiras e cascatas e por abrigar no Parque Nacional de São Joaquim, o ponto mais alto do Sul do Brasil, o Morro da Igreja (altitude de $1.822 \mathrm{~m})$.

O Morro da Igreja, localizado em Urubici, é um dos atrativos com expressivo potencial para o turismo de aventura e ecoturismo, onde as possibilidades de investimento encontram se no mapeamento de trilhas e na elaboração e aperfeiçoamento de roteiros voltados às atividades de aventura tais como mountain bike, rappel, trekking e arvorismo (Acorde, 2009), que podem ser integradas à visitação aos vinhedos.

A cidade de Bom Retiro possui potencial para o turismo religioso, porém, no caso deste estudo, evidencia-se que, apesar de possuir um dos vinhedos da Villa Francioni e outros projetos vitivinícolas, assim como o empreendimento de agroturismo Curucaca Hotel Fazenda, praticamente não se integra ao roteiro Serra Catarinense, apontado pela SANTUR.

Propõem-se, ainda, um roteiro composto por diversos vinhedos que se encontram próximo à região central do município de São Joaquim e, no caso das vinícolas Villa Francioni e Villaggio Bassetti, se localizam junto à SC 438, elemento facilitador na acessibilidade do turista. Para a visitação aos vinhedos das vinícolas Quinta da Neve e Suzin sugere-se a organização de passeios em veículo of Road ou cavalgadas, devido à qualidade da via de acesso. A associação da visitação em vinhedos aos passeios em veículo of Road retrata uma das perspectivas do enoturismo proposta por Enrique Torres Bernier ${ }^{19}$, na qual outras atividades são vinculadas ao vinho, tornando-o um pretexto turístico.

Para pensarmos um modelo de roteiro enoturístico que integre a propriedade da vinícola Santo Emílio, faz-se necessário destacar sua proximidade do Hotel Fazenda do Barreiro e as possibilidades de atrativos da cidade de Urupema, como por exemplo, a criação de trutas, que podem resultar em investimentos relacionados ao turismo de pesca esportiva e em restaurantes típicos a base de truta e comida campeira. Cabe destacar ainda, que o Hotel Fazenda do Barreiro oferece cavalgadas para a região da Coxilha Rica, relembrando a atividade tropeira na região e que poderia integrar a visitação à vinícola Quinta da Neve.

No caso do último roteiro enoturístico proposto, parte encontra-se nas proximidades da Rodovia SC 438, que liga a cidade de São Joaquim à Lages, o que sugere uma relação com a herança cultural tropeira fortemente percebida na comunidade local e inclusive, na oferta dos meios de hospedagem, os tradicionais hotéis fazenda (Boqueirão e Pedras Brancas). Estes empreendimentos são símbolos da oferta turística da Serra Catarinense, sendo responsáveis pela captação de grande parte dos visitantes à região.

Cabe destacar, que o planalto serrano possui uma enorme diversidade quanto às suas características naturais (reflexo da exuberante paisagem de campos naturais e matas de araucárias) e às incursões dos povos que participaram da construção da sua história, da apropriação e das modificações deste espaço. O turismo, na Serra Catarinense, poderá

\footnotetext{
${ }^{19}$ Professor da Universidade de Málaga (Espanha).
} 
mobilizar ainda mais os fluxos de investimentos, o empreendedorismo e o incremento da oferta de empregos e geração de renda para a sua população. Basta que o poder público atue de forma mais integrada, trabalhando o destino Serra Catarinense, instituído pela SANTUR.

Assim, a perspectiva de associar a oferta turística existente ao turismo do vinho, representa um importante negócio para o setor de turismo e para a vitivinicultura local que ainda inicia suas atividades. A rota enoturística da região de São Joaquim sugerida por esta investigação foi fragmentada em três opções de roteiros, que pretendem incrementar e articular a oferta enoturística regional, sem privilegiar um município em detrimento de outro. Esta proposta visa incentivar, sobretudo a ACAVITIS, na elaboração de produtos que aproveitem os equipamentos e serviços existentes, valorizando os atrativos naturais e culturais de cada comunidade e promovendo o surgimento de incursões turísticas inovadoras, assim como o incentivo às melhorias e novos investimentos no setor.

De acordo com Boullón (2002, p. 79), “o espaço turístico é consequência da presença e distribuição territorial dos atrativos turísticos que, não devemos esquecer, são a matériaprima para o turismo". Se considerarmos que "o espaço é a síntese, sempre provisória entre o conteúdo social e as formas espaciais" (Santos, 1997, p. 88), a paisagem (urbana ou natural) reveste-se de atributos que geram atratividade e motivação no deslocamento dos turistas, possibilitando o crescimento e o desenvolvimento desta economia.

\section{CONSIDERAÇÕES FINAIS}

O recente dinamismo da vitivinicultura na região de São Joaquim aponta para os investimentos pioneiros da Vinícola Quinta da Neve, com vinhedo implantado no ano 2000 e o primeiro vinho lançado em 2004, e da Vinícola Villa Francioni, com vinhedos implantados em 2001 e o lançamento do primeiro vinho em 2005. Entre os empresários há pessoas descendentes de italianos do Sul do Estado de Santa Catarina, do Estado do Rio Grande do Sul e do Estado do Paraná, regiões cujo capital tem origem na pequena produção mercantil do Sul do Brasil, onde se instalaram os imigrantes, definindo e dinamizando estas áreas coloniais.

Há que se ressaltar que, os empresários pioneiros do setor vitivinícola de altitude de São Joaquim no ano de 2010 eram representados pelas oito primeiras vinícolas que comercializavam seus vinhos no mercado nacional. Destaca-se que todos os investidores estão ligados a diferentes setores, como o setor têxtil, o cerâmico, a fruticultura, a indústria madeireira, a pecuária e a comunicação, enfatizando que 50\% destes (Suzin, Sanjo, Serra do Sol e Santo Emílio) já possuíam outros negócios na região e a outra metade não (Quinta da Neve, Villa Francioni, Quinta Santa Maria e Pericó). As vinícolas Villaggio Bassetti e Monte Agudo integram os investidores oriundos de outras regiões do estado e a vinícola Hiragami apesar de possuir negócios na região, fortalece a tendência de diversificação de atividade evidenciada no setor de fruticultura temperada. 
Evidentemente, estas vinícolas estão fazendo uso de estratégias competitivas para atraírem o público consumidor, mobilizando a compra com base na qualidade, no diferencial e na singularidade das bebidas e valorizando as características únicas obtidas nas áreas de altitude da serra catarinense. Cabe destacar o associativismo que resultou na constituição da ACAVITIS em 2005, visando defender os interesses dos produtores de uvas e vinhos de altitude de Santa Catarina. Para isso, estabeleceram três ações mestras, a) a consolidação da marca coletiva ACAVITIS e a certificação dos vinhos finos de altitude (parceria Epagri, Embrapa Uva e Vinho e SEBRAE), b) a construção de uma sede em São Joaquim (apoio da prefeitura de São Joaquim), e c) a implantação do Projeto de Enoturismo (parceria com o SEBRAE).

Com a inserção das atividades vitivinícolas na região, surge a oferta do enoturismo, que desponta como uma atividade promissora, capaz de redirecionar a economia regional e apresentando-se como uma consequência aos investimentos vitivinícolas instalados. Atualmente, o turista pode visitar, em São Joaquim, as instalações da Vinícola Villa Francioni, adequadas para as incursões enoturísticas e a loja e a fazenda da Vinícola Quinta Santa Maria, que também oferece passeios aos vinhedos com almoço servido às margens do rio que corta a propriedade.

Contudo, cabe enfatizar que para a consolidação da oferta enoturística da região de São Joaquim ocorrer, faz-se necessária a articulação do empresariado dos setores de turismo e vitivinicultura, através do associativismo (ACAVITIS), que mobilizará o poder público e as instituições de ensino locais/regionais no sentido de estimular um comprometimento mútuo com o incremento deste produto. Estes devem fazer uso dos atuais projetos iniciados na região como o Programa de Ação Conjunta de Revitalização e Desenvolvimento - Acorde, região de São Joaquim, o Plano de Marketing Turístico do Estado de Santa Catarina - Plano Catarina e as ações do Ministério de Turismo direcionadas ao Destino Indutor São Joaquim.

Neste cenário, o presente estudo ousou propor uma rota enoturística para a região de São Joaquim, composta de três opções de roteiros (Roteiros enoturísticos: Serra do Panelão Serra do Corvo Branco, Vinícolas do Pericó - Serra do Rio do Rastro e Central) capazes de incrementar e articular a oferta enoturística regional, de forma integrada e sem privilegiar um município em detrimento de outro. Esta proposta pretende incentivar a elaboração de produtos que utilizem os atuais equipamentos e serviços disponíveis, motivando novos investimentos e valorizando os atrativos naturais e culturais de cada comunidade por meio da promoção de incursões turísticas inovadoras.

\section{REFERÊNCIAS}

Acorde - Ação Conjunta de Revitalização e Desenvolvimento. (2009). Relatório de caracterização geral da região - dados secundários. Balneário Camboriú: UNIVALI. 
Aguiar, M. (2008). O vinho na era da técnica e da informação: um estudo sobre Brasil e Argentina. Belo Horizonte: Autêntica.

Ansarah, M. G. dos R. (2005). Turismo e segmentação de mercado: novos segmentos. In L. G. G. Trigo et al. (Org.). Análises regionais e globais do turismo brasileiro (pp. 285-299). São Paulo: Roca.

Blume, R. Hoff, D. N. Pedrozo, E. A. (2007). Potencialidade competitiva e recursos essenciais à produção de vinhos finos: um estudo da vitivinicultura em São Joaquim, SC. Anais do Congresso Brasileiro de Economia e Sociologia Rural, Londrina, PR, Brasil, 45.

BRDE - Banco Regional de Desenvolvimento do Extremo Sul (2005). Vitivinicultura em Santa Catarina: situação atual e perspectivas. Florianópolis: BRDE. 83.

Boullón, R. C. (2002). Planejamento do espaço turístico. Bauru: EDUSC.

Cholley, A. (1964). Observações sobre alguns pontos de vista geográficos. Boletim geográfico. Rio de Janeiro: CNG, 12(180), 267-276.

Confraria do Vinho - Bento Gonçalves. A nova arquitetura do vinho. Recuperado em 10 setembro 2010, de http://www.confrariadovinho-bg.com.br/index.php?id=38.

Falcade, I. (2001). O espaço geográfico e o turismo na Região da Uva e do Vinho no nordeste do Rio Grande do Sul. Encontro Estadual de Geografia, Caxias do Sul, RS, Brasil, 21.

Hall, M. Sharples, L. Cambourne, B. Macionis, N. (2004). Wine tourism around the world: development, management and markets. Oxford: Elsevier.

Lins, H. N. (2008). Estilização do turismo: ensaio com foco na serra catarinense. Anais do Encontro de Economia Catarinense, Chapecó, SC, Brasil, 2.

Mamigonian, A. (1996). A geografia e "A formação social como teoria e como método". In M. A. A. Souza (Org). O mundo do cidadão um cidadão do mundo. São Paulo: Hucitec.

Santos, M. (1982). Espaço e Sociedade (2a ed). Petrópolis: Vozes. . (1997). A natureza do espaço: técnica e tempo, razão e emoção (2ª ed). São Paulo: Hucitec.

Tonietto, J. (2003). Indicações geográficas para vinhos brasileiros. Recuperado em 10 abril 2010, de http://sistemasdeproducao.cnptia.embrapa.br/FontesHTML/Uva/UvasViniferasRegioesClimaTe mperad o/indicacoes.htm.

Xavier, H. (2007). A percepção geográfica do turismo. São Paulo: Aleph. 